\title{
A Study on Green Supply Chain Management (GSCM)
}

\author{
Ayush Agarwal, B.E. Mechanical Engineering, Vishwakarma Institute of Technology Pune India, \\ aayushagarwal808@gmail.com
}

\begin{abstract}
In order to integrate the concern related to environment and supply chain management Green Supply Chain Management (GSCM) has emerged as an environmental innovation. Recently, it has gained popularity amongst practitioners and the academicians. It is also defined as the process of using environmentally friendly inputs and transforming the same into outputs that can be re-used at the end of its life cycle. It is treated as one of the most recent innovation for the improvement in the supply chain management competencies. The major activities under GSCM includes green design, green manufacturing, packaging, waste management and reversal of the logistics. GSCM has emerged as one of the key approaches for the organization whose prime focus is to become an environmentally sustainable enterprise. It is expected that in order to reduce the environmental impact of the various products and services, the organization will implement the strategies relating to it. Organizations have increased the awareness regarding environment due to the competitive, regulatory and marketing pressure.
\end{abstract}

Keywords - Supply Chain Management, Green Supply Chain Management (GSCM), Innovation, Environment, Green Design, Manufacturing \& Packaging, Waste Management \& Reversal of Logistics

\section{INTRODUCTION}

Since last two decades the environment issues are rising on a faster pace which is a serious cause of global warming and issues relating to environment. Also, the scarcity of the resources and the pollution level is affecting the human life, flora \& fauna and increasing the diseases like cancer, heart disease, hepatitis, yellow fever etc. Through the adoption of green practices in the various business operations, the concept of green supply chain management has occurred in order to alleviate the environmental degradation, water \& waste management. The basic ideology behind the green concept is to enhance the sustainability regarding environment and this helps in reducing the pollution, production cost, increase customer satisfaction, positive image, reputation, increase in economic growth and provision of increasing the exporting of products to the proenvironmental countries.

The term green supply chain refers to the idea of integration of sustainable environmental processes into the traditional supply chain method which includes processes like selection of supplier, purchasing material, designing, manufacturing \& assembling of product, distribution and end-of-life management. GSCM involves the value creation rough the operations of whole chain and helps in alleviating the harmful impact of business and supply chain operations. The aim of GSCM is reducing air, water and waste pollution and enhancing of green operations also related to less waste manufacturing, reuse \& recycling of products, reduction in manufacturing costs, greater efficiency of assets, positive image building, and increase in customer satisfaction. In short, GSCM is all about making the entire supply chain more environmentally sustainable.

Now the consumers are getting more aware of the products that they are purchasing, and the companies can expect questions regarding the GSCM for their manufacturing, supply chain management and recycling of the products. The companies may adopt the GSCM for the following reasons:

- To differentiate oneself in a competitive industry by being the eco-friendly company

- Out of compulsion due to the rules \& regulations.

- Due to increase in the awareness of customers and regulatory norms

- To have a competitive advantage on the companies that have not adopted GSCM approach.

- Creating value for the customers and stakeholders.

\section{KEY DRIVERS FOR THE IMPLEMENTATION OF} GREEN INITIATIVES

Government Compliance - Going green does not only impact the strategy and thinking of the company but also has an influence on the chain management. The focus is towards making the supply chain eco-friendlier along with the cleaner water consumption and alternate energy sources. Government has the power to act as a driver for the implementation of GSCM by following three methods:

- The Government needs to get engaged in transparent regulations regarding environment 
- The Government needs to engage in the various activities and educate people for creating a green and clean environment.

- The Government should promote the green innovations in the important areas of GSCM.

- Reverse Logistics - Logistics involves a range of activities like collection, sorting, processing and reconditioning. The purpose of the reverse logistics process is to make sure that the material is returned from the user to the producer for recycling, reused and reconditioned. The reverse logistics represents planning, measuring and execution flow for raw materials and finished products and aims at recovering and recycling of those products or materials.

- Supply Chain Efficiency - In order to reduce operating costs and improve the customer services, organizations are integrated the supply chains and these processes allows to reduce the unnecessary waste and pollution. Manufacturing and production related operations are considered as an enemy to the environmental protection and the businesses that wants the transition to GSCM should take the opportunity to review all their processes related to businesses in order to identify areas where adopting a greener outlook can improve the businesses.

- Economic Benefit - It can act as a driver of GSCM and represents the ability to reduce the unit cost of the manufactured goods \& services without affecting or reducing the quality of the product. The removal of non-value adding components of the products can also lead to the reduction in costs. The economic benefit can be obtained by using less energy, water and raw materials in the production process which will help in reducing the production cost. The implementation of GSCM is considered as a win-win situation which helps in reducing costs, improving operational efficiencies and improving the reputation of the organization.

- Corporate responsibility - The organization has an obligation to the stakeholders, society, environment apart from the investors. Many corporations have already turning to ISO i.e. International Organization for Standardization for the guidance and implementing various CSR programs like ISO 9000 standard is used for quality, ISO 14000 standard is used for environmental management system and established best practices and benchmarking for the greener initiatives, ISO 26000 standard is used for establishing a framework for the development of CSR standards. The green policies are look for the ways in which the firm can improve the credentials regarding green initiatives.

\section{ROLE OF CRITICAL SUCCESS FACTORS IN IMPLEMENTING GSCM}

There are six critical success factors for implementing the GSCM:

- Internal Management - It contains support and encouragement from senior managers and acts as a key critical success factor for enterprises to adopt green practices. The senior management encourages and support the methods related to the environmental protection which motives the employees as well. The perception of the risks related to environment could also bring the positive impact in the adoption of the green practices.

- Supplier management - Strong collaboration with the suppliers boosts the adoption, enhances the incentive systems and development of the ecofriendly ideas. The practices related to GSCM is adopted only with the active participation of the customers and suppliers as it may help in generating the enhancement in operational and environmental performance in order to achieve economic goals of firms.

- Customer Management - Customers plays an important role in adopting GSCM. The developing countries are facing heavy pressures in order to adopt the green practices in their business operations, so as to meet the demand of the customers and remain competitive in the market.

- Competitiveness - It is one of the significant factors for the implementation of the green practices along with the organizations goal to protect the environment.

- Social factors - It plays an important role in the implementation of GSCM. The factors like increasing awareness of customers on the environment, growing attention of the regulatory bodies, firms have to exchange end to end information pertaining to the operations of supply chain management with the community. Moreover, many NGO's, electronic and social media is also putting pressure on the firm to adopt the green practices.

- Regulatory - Governmental bodies are enacting various environmental laws in order to control the climate change, global warming, pollution and the firms are required to reduce the negative effect of their supply chain on the sustainability of environment.

GREEN PRACTICES IN SUPPLY CHAIN
MANAGEMENT




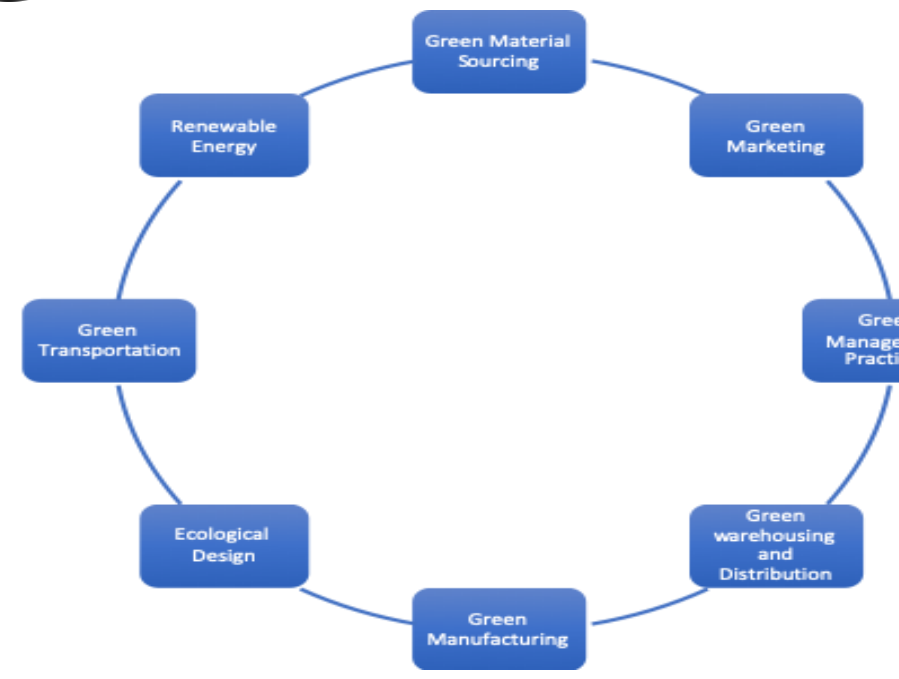

Fig 1.1: Green Practices in Supply Chain Management

- Green Material Sourcing - Green sourcing means purchasing of materials and components which have eco-friendly features like reusability, recyclability and non-existence of hazardous chemicals. The role of ecofriendly purchasing includes the involvement of recycling and remanufacturing. In order to alleviate the waste, air and water pollution, the adoption of green purchasing in supply chain and business operations acts as a reliable tool

- Green marketing - A broad range of marketing activities like planning, process, price, promotion, production and after sale service is designed to clarify the goals of an organization in order to alleviate the harmful effects of the products. It contains the activities that have the minimum negative effect on the environment and promotes the products that have environmentally friendly properties. It also helps in enhancing the competitiveness of the firms along with the financial and environmental performance.

- Green Management Practices - It provides an extra source of information that can enhance the objectives related to business \& environment. Adoption of this practice helps in improving the firm's image, increase in efficiency, cost savings, reduction of carbon emissions etc.

- Green warehousing and distribution - It can help in reducing the wastes and plays an important role in the reduction of energy and value addition of green products in the warehouse that improves an overall performance of the organization and projects a better image of the same.

- Green manufacturing - This practice includes implantation of the socially and environmentally accountable practices in order to reduce the harmful effects of manufacturing and increasing the profitability. This involves the application of the green resources which may lead to the competitive advantage through reduction in cost of the product and improvement in the quality of product.

- Ecological design - It includes the usage of cleaner technology processes, green raw material and components. It also reduces the ecological impacts of products during the life of the products. Apart from these advantages, it also supports recycling, reusing and remanufacturing of the products which in turn helps in reducing the costs.

- Green Transportation - Logistics overheads can be saved by promoting the efficiency and enhancing the customer association. The activities related to logistics integrates with the reverse logistics i.e. reusing, recycling and manufacturing which can produce the products that are re-usable. This also helps the firm to reduce the environmental impacts with improved quality and cost reductions.

- Renewable energy - The supply chain operations depend on the energy and the fossil fuel which are treated as the main reasons for pollution, global warning and climate change. Renewal energy including biofuel are required in supply chain operations to obtain the sustainable economic and environmental growth.

\section{BENEFITS OF GREEN SUPPLY CHAIN MANAGEMENT}

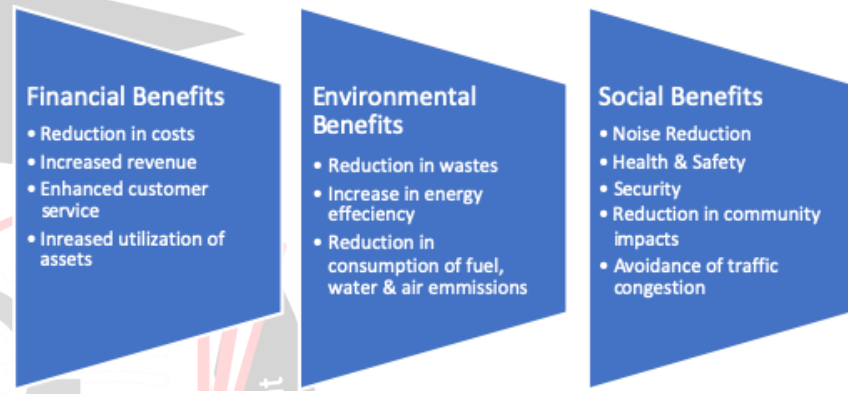

Fig 1.2: Benefits of Green Supply Chain Management

\section{$\begin{array}{llll}\text { SUCCESS STORIES OF VARIOUS } & \text { OF }\end{array}$ ORGANIZATIONS}

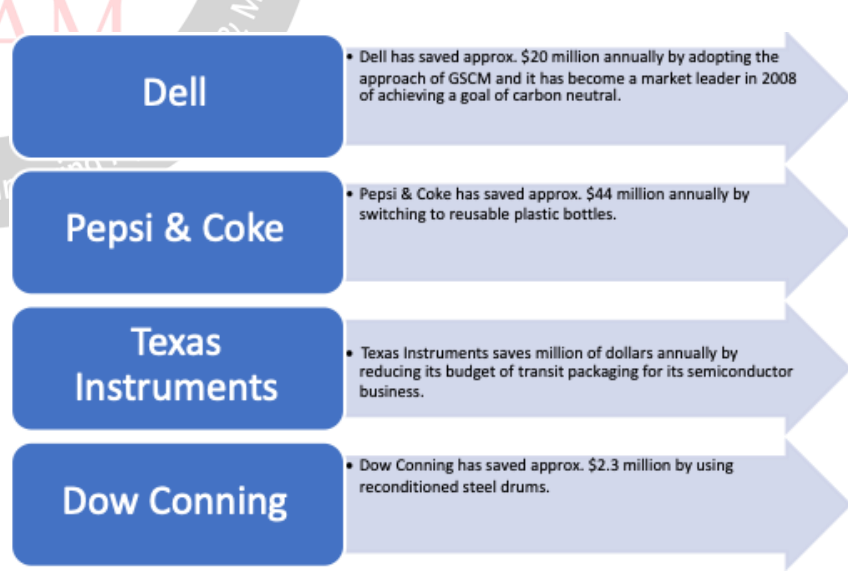

Fig 1.3: Success Stories

\section{BARRIERS FOR IMPLEMENTING GSCM}

Tradition supply chain management was focused on balancing the benefits among stakeholders in order to improve the operating efficiencies throughout the facilities and to maximize the profits. On the other hand, the top priority of GSCM is to focus on social responsibilities, economic gains and environmental concerns. The common barriers for implementing the same is as follows:

- Lack of integration of IT system

- Lack of acceptance of new technology 
- Poor organizational culture

- Lack of government initiatives

- Lack of skilled human resource professionals

- Uncertainty and increased competition in the market

- Lack of implementation of green practices within a supply chain

- High investment cost

- Customers unawareness towards GSCM products

- Lack of knowledge and experience

- Lack of training of using GSM products

- Lack of external sustainability audits for suppliers and contractors

- Lack of initiatives of management for transport and logistics

- Lack of waste management of the organization

- Lack of sustainability certification like ISO 14001

- Lack of green practitioners like green architects, consultants and contractors

\section{LITERATURE REVIEW}

The article of regarding GSCM was developed by Kelle \& Silver, $1989{ }^{[1]}$ and it was developed as an optimal forecasting system to use to forecast the products that can be reused. The concept of green supply chain came into existence in 1989. This system of forecasting was controversial, as returning individual containers is not known with certainty and, therefore, their studies may somewhat be confusing.

The first literature of GSCM was came into context by Navin Chandra in $1991\left[^{2}\right]$ which considered the need for a green design in order to reduce the impact of wastage of product. It also gained popularity with both academics and practitioners in order to aim at reducing waste and preserving the quality of product-life and the natural resources. In order to achieve the best practice, eco-friendly and re-manufacturing processes were considered as two important assets.

As per Kleindorfer PR, Singhal K, Wassenhove LN, 2005 $\left[{ }^{3}\right]$, one of the best strategies for meeting the challenge in order to reduce the carbon emission and enhance sustainability is the implementation of GSCM. In managing any business, the rapid change in global manufacturing scenario, environment and social issues are becoming important and compulsory. The GSCM is an approach which is used to improve performance \& the processes of the products keeping in mind the predefined requirements of the environmental regulations issued by government. These regulations aims at confining the wastes within the industrial system so that energy resources are conserved and prevent the spreading of harmful materials into the environment.

\footnotetext{
${ }^{1}$ []. Kelle \& Silver. Environmental Purchasing : A Framework for Theory Development. European Journal of Purchasing \& Supply Management, Vol. 7,No.1, 64-75, 1989.

${ }^{2}$ []. Navin Chandra. Green supply chain management, economic growth and environment: A GMM based evidence. Journal of Cleaner Production. 2017;185:588-599, 1991.

${ }^{3}$ [] Kleindorfer PR, Singhal K, Wassenhove LN. Sustainable operations management. Production and Operations Management. 2005;14(4):482492
}

Khan et al, $2017\left[^{4}\right]$, has highlighted the practices of the GSCM provides an opportunity to capture new markets and export to pro-environmental countries like USA, Germany, UK and Poland. This practice have been considered as a tool for firms to decrease the costs related to products, enhances the profitability and increases the market share. Organization also adopts green practices in their regular business activities in order to improve social performance. The social performance specifies the improvement in the life standard of people without compromising on the beauty of environment. Additionally, social performance also includes the image enhancement, improvement of environmental sustainability and reduction in the risks related to environment. Another factor which is considered the most in order to implement the green practices in the supply chain operations is the minimization of the costs. The implementation of such initiatives would help to cut down the costs of packaging, components and materials as an effect of reused, recycled and remanufactured products.

As put forth by Rao, Holt, $2007\left[{ }^{5}\right]$, the greening of supply chains can increase the edge in the competitive environment along with the economic performance of organization. Manufacturing organizations that are involved in green project partnership with their suppliers and customers can develop the capabilities that will reflect performance related to cost, quality and environment. He further stated that it can result in cost reductions, improvement in operational efficiencies, greater flexibility, sales enhancement, customer value enhancement and societal image improvement. However, there is a high initial investment in GSCM, and this includes adoption of advanced technologies, hiring, motivating and training good quality employees.

Hajikhani, Wahat \& Idris, $2000\left[^{6}\right]$ had argued that the demand of the customers for the green products and services is considered as one of the most significant factors for green initiatives. Customers are becoming increasingly aware of the negative impact caused by certain businesses activities on the environment and they are exerting pressures on organizations to implement greener supply chains which helps in reducing the harm towards an environment. They also said that these days consumers are requesting for the green products.

D Holt \& A Ghobadian, $2010\left[^{7}\right]$ had mentioned that while making purchasing decisions, customers take the environment into consideration and they demand green products by asking for ISO 14001 certification. The customers act as a driver for organizations in order to adopt

\footnotetext{
${ }^{4}[]$. Khan et al, Study of Green Supply Chain Management in the Indian Manufacturing Industries: A Literature Review cum an Analytical Approach for the measurement of performance, IJCEM International Journal of Computational Engineering \& Management, Vol. 13, July 2017

${ }^{5}$ []. P Rao \& D Holt, 2007. Do green supply chains lead to competitiveness and economic performance? International Journal of Operations and Production Management 25(9):898-916.

${ }^{6}[]$ M Hajikhani, Wahat \& KB Idris, 2000. Considering on green supply chain management drivers as a strategic organizational development approach; a Malaysian perspective. Australian Journal of Basic and Applied Sciences 6(8):146-165.

7 [] D Holt \& A Ghobadian, 2010 "An Empirical Study of Green Supply Chain Management.
} 
GSCM practices and the media plays an important role in informing and educating the public on the degradation of environment, therefore, causing a concern of environmental issues for the customers. This may further lead to less buying of the products as they are considered as environmentally harmful. This drives organizations to look at the implementation of GSCM practices and affects the entire manufacturing process starting from the phase of design to the end-of-life of the product.

Another study was conducted by Large \& Thomsen, 2012 $\left[{ }^{8}\right]$ and identified five potential drivers of green supply chain management performance i.e. the capabilities regarding GSCM, the level of purchasing department, environmental commitment, the degree of green supplier assessment, and the degree of green collaboration with suppliers. They further examined the links between green practices of supply chain management and supply chain performance in the context of the automotive supply chain and their study obtained that the conceptual model from data analysis provides an evidence as to which green practices have positive effects on quality \& customer satisfaction.

In the study conducted by Chiou et al, $2012\left[{ }^{9}\right]$ in Taiwan has explored the relation between greening the supplier and green innovation in Taiwan industry by using Structural Equation Modeling. Their study concluded that greening the supplier leads to significant benefits to the environmental performance and competitive edge of the firm. They also examined the GSCP that has been adopted by Third Party Logistics (3PLs) service providers like implementation of specific practices and level of adoption of each practice.

According to AMF Paco, MLB Raposo, WL Filho 2010 [ $\left.{ }^{10}\right]$ many firms have implemented GSCM practices like investment recovery, eco-design and internal environmental management and with the integration of the green factor. Moreover, eco-design can be identified as a design for environment with an aim to reduce environmental impact throughout the product development and the entire product life cycle from acquiring raw materials from suppliers to manufacturing, using and disposing those materials. In this study, the practices of green product and process design includes utilization of environmentally friendly materials, designing products for reduced consumption of material and energy, designing

\footnotetext{
${ }^{8}$ [] RO Large \& CG Thomsen, 2012 "Drivers of Green Supply Chain Management Performance: Evidence from Germany", Journal of Purchasing and Supply Management, Vol. 17, pp 176-184.

${ }^{9}$ [] TY Chiou, HK Chan, F Lettice \& SH Chung, S.H., (2012) "The Influence of Greening the Suppliers and Green Innovation on Environmental Performance and Competitive Advantage in Taiwan", Transportation Research Part E, 47, pp 822-836.

${ }^{10}$ [] AMF Paco, MLB Raposo, WL Filho, 2010. Identifying the green consumer: a segmentation study. Journal of Targeting, Measurement and Analysis for Marketing 17(1):17-25.
}

products for reuse, recycle and recovery of material and component parts, avoiding or reducing the use of hazardous products, optimizing process to reduce solid/liquid waste and emission and using reverse logistic for product and/or manufacturing process and these practices have a significant impact on the performance sustainability.

\section{RESEARCH METHODOLOGY}

Research methodology provides logical and systematic sequence of various research steps and methods which are based on scientifically proved procedures in order to achieve the objectives of research. Methodology ensures objectivity and consistency in procedures thus provides more reliable results. The fundamental motive of conducting a research study for any field of academia is to solve the problems of society and improve the life of human beings. In modern scientific world, data can obtain from primary sources and secondary sources by using modern techniques.

\section{RESEARCH DESIGN OF THE STUDY}

The nature of present dissertation is qualitative, and the researcher attempts to find out the current status of aviation industry`s impact on climate change.

The nature of data collected was qualitative and was analyzed using content analysis technique. Content analysis is a tool for measuring the content of communication. Its objective is to obtain a qualitative description of the manifest content of communication. In content analysis the responses from different respondents are compares and summarized according to the objectives of the study. The qualitative data obtained was analyzed using content analysis to present the findings of the study.

Content analysis is the best method of analyzing the openended questions. It is suitable because of its flexibility and also allows for objective, systematic and quantitative description of the content of communication. Research studies that have employed this technique include.

\section{SOURCES OF DATA}

The study used both primary and secondary data for the study. Primary data was collected through a structured interview schedule consisting of open-ended questions, and such findings were again discussed with experts to draw meaningful inferences.

Whereas secondary data was collected from utility articles from journals, magazines, etc.

\section{SAMPLE DESIGN AND SIZE}

Planning of sampling design is very important for the field survey. Therefore, for the purpose of this study Convenience Sampling Method has been employed. 
The questionnaire for collecting primary data was obtained after in-depth interviews with Senior manager position in the supply chain, procurement and environmental department. Interview was adopted for the study because it is relatively brief, easy to execute, quickly analyzed and inexpensive. The selection criteria ensured that participants had the relevant knowledge required to answer questions.

\section{ANALYSIS FRAMEWORK}

1. What is the primary type of the business conducted by your organization

\begin{tabular}{|l|c|}
\hline Manufacturing & $50.0 \%$ \\
\hline Trade i.e. wholesale or retail & $17.0 \%$ \\
\hline Logistics & $5.8 \%$ \\
\hline Real Estate & $3.8 \%$ \\
\hline Environmental Waste Disposal & $2.0 \%$ \\
\hline Consulting & $2.0 \%$ \\
\hline Banking & $1.9 \%$ \\
\hline None & $1.9 \%$ \\
\hline Service & $1.9 \%$ \\
\hline Service based & $1.9 \%$ \\
\hline Education & $1.9 \%$ \\
\hline Metal Testing & $1.9 \%$ \\
\hline Software & $1.9 \%$ \\
\hline Construction & $1.9 \%$ \\
\hline Banking & $1.9 \%$ \\
\hline Engineering \& sustaining & $1.9 \%$ \\
\hline
\end{tabular}

Table 5.1: Type of the business

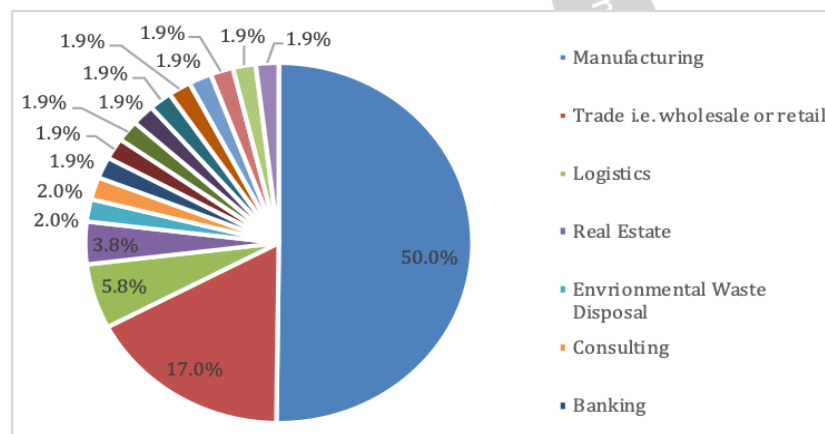

Figure 5.1: Type of the business

\section{Interpretation}

It is clear from the above analysis, that $50 \%$ respondents are employed in manufacturing industry, $17 \%$ respondents are employed in Trade i.e. wholesale or retail industry, $5.8 \%$ respondents are employed in Logistics sector, 3.8\% respondents are employed in real estate sector, 2\% respondents are employed in Environmental Waste Disposal sector, 2\% respondents are employed in Consulting sector, $1.9 \%$ respondents are employed in Banking sector, $1.9 \%$ are employed in none of the industries or sectors, $1.9 \%$ are employed in service industry, $1.9 \%$ are employed in service based industry, $1.9 \%$ are employed in education sector, $1.9 \%$ are employed in metal testing industry, $1.9 \%$ are employed in software industry, $1.9 \%$ are employed in construction sector, $1.9 \%$ are employed in banking sector \& $1.9 \%$ are employed in engineering \& sustaining industry.

2. What are the drivers of implementation of Green Supply Chain Management

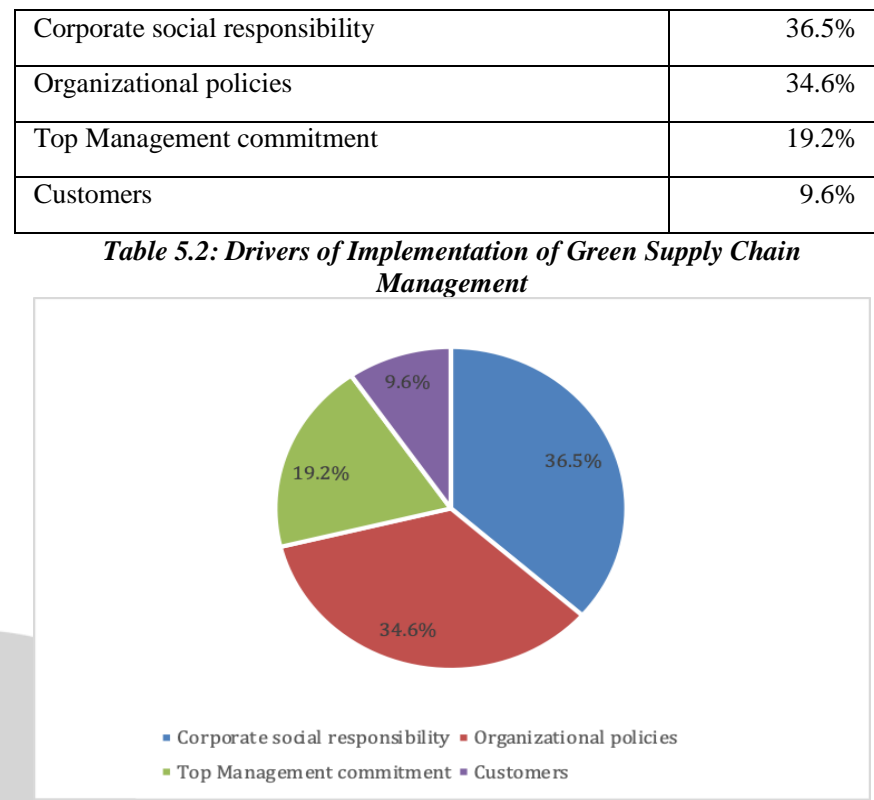

Figure 5.2: Drivers of Implementation of Green Supply Chain Management

\section{Interpretation}

It is clear from the above analysis that in the implementation of Green Supply Chain Management, the impact of corporate social responsibility is $36.5 \%$, organizational policies is $34.6 \%$, top management commitment is $19.2 \%$ and customers is $9.6 \%$.

3. What are the barriers in implementation of green supply chain management

\begin{tabular}{|l|r|}
\hline Cost & $32.7 \%$ \\
\hline Unawareness of customers & $34.6 \%$ \\
\hline Corruption & $7.8 \%$ \\
\hline Technology & $9.6 \%$ \\
\hline Government Legislations & $9.6 \%$ \\
\hline Cost as well as technology along with consumers unawareness & $1.9 \%$ \\
\hline Consumer behavior, market nerve and alternatives to your product & $1.9 \%$ \\
\hline NA & $1.9 \%$ \\
\hline
\end{tabular}

Table 5.3: Barriers in Implementation of Green Supply Chain Management

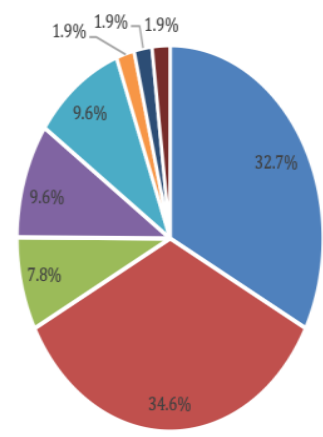

- Cost

- Unawareness of customers

- Corruption

- Technolog

- Government Legislations

- Cost as well astechnology along with consumers unawareness - Consumer behaviour, market nerve and altematives to your product - NA

Figure 5.3: Barriers in Implementation of Green Supply Chain Management 


\section{Interpretation}

It is clear from the above analysis that the barriers for implementing the Green Supply Chain Management, cost factor plays an important role i.e. the impact of this factor is $32.7 \%$, followed by Unawareness of customers i.e. $34.6 \%$, Corruption is $7.8 \%$, Technology is $9.6 \%$, Government Legislations is $9.6 \%$, cost as well as technology along with customer awareness is $1.9 \%$, consumer behavior, market nerve and alternatives to the products is $1.9 \%$ and NA category is $1.9 \%$.

4. Is the top management of your company aware of the concept $\&$ benefits of Green Supply Chain Management

\begin{tabular}{|l|r|}
\hline Yes & $55.8 \%$ \\
\hline No & $9.6 \%$ \\
\hline Maybe & $34.6 \%$ \\
\hline
\end{tabular}

Table 5.4: Awareness of the concept \& benefits of Green Supply Chain Management

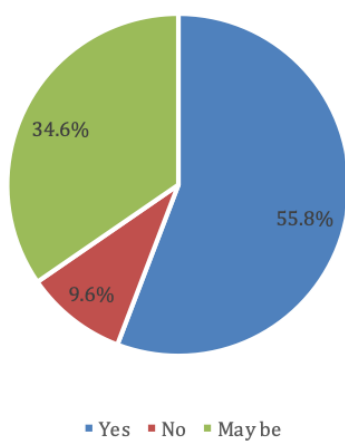

Figure 5.4: Awareness of the concept \& benefits of Green Supply Chain Interpretation Management

As per the above analysis, it is clear that $55.8 \%$ respondents says that their top management is aware of the concept \& benefits of Green Supply Chain Management, 9.6\% denies the same and $34.6 \%$ says that they are not sure that the top management is aware of the same.

5. Does the organization use Green Supply Chain Management Practices like Green Supplies, Green Manufacturing, Green Packaging, Green Logistics

\begin{tabular}{|l|c|}
\hline Yes & $26.9 \%$ \\
\hline To some extent & $48.1 \%$ \\
\hline No & $25.0 \%$ \\
\hline
\end{tabular}

Table 5.5: Application of Green Supply Chain Management Practices

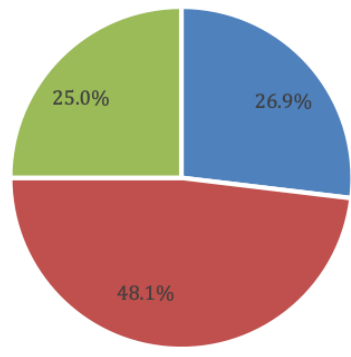

"Yes = To some extent " No

Figure 5.5: Application of Green Supply Chain Management Practices

\section{Interpretation}

It is clear from the above analysis, that $26.9 \%$ respondents say that their organizations have applied the Green Supply Chain Management Practices, $48.1 \%$ respondents say that to some extent it has been applied and $25 \%$ respondents denies the same.

6. Which of the following practices does your organization uses

\begin{tabular}{|l|r|r|}
\hline Green Procurement & 11 & $21.2 \%$ \\
\hline Green Logistics & 14 & $26.9 \%$ \\
\hline Environment friendly packaging & 30 & $57.7 \%$ \\
\hline Green Suppliers & 12 & $25.0 \%$ \\
\hline Recycling of waste & 1 & $3.8 \%$ \\
\hline Life sciences and into green manufacturing & 1 & $3.8 \%$ \\
\hline None at present & 1 & $1.9 \%$ \\
\hline Not sure & & \\
\hline
\end{tabular}

Table 5.6: Practices that has been put in the practice by the organization

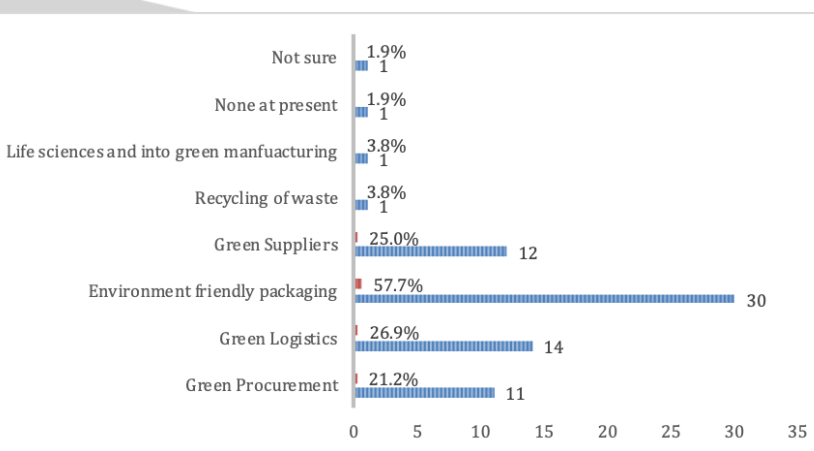

Figure 5.6: Practices that has been put in the practice by the organization

\section{Interpretation}

It is clear from the above analysis, that the organization uses $57.7 \%$ of the environmentally friendly packaging, $26.9 \%$ of Green Logistics, $21.2 \%$ of Green Procurement, $25 \%$ of Green suppliers, $3.8 \%$ of recycling of waste, $3.8 \%$ of life sciences \& into green manufacturing, $1.9 \%$ denies the same $\& 1.9 \%$ are not sure about the same.

7. What do you think that using the Green Supply Chain Management practices is necessary for the legal compliance

\begin{tabular}{|l|r|}
\hline Yes & $53.8 \%$ \\
\hline No & $38.5 \%$ \\
\hline To Some extent & $8.0 \%$ \\
\hline \multicolumn{2}{|c|}{ Table 5.7: Usage of Green Supply Chain Management Practice is must }
\end{tabular}
for the legal compliance 


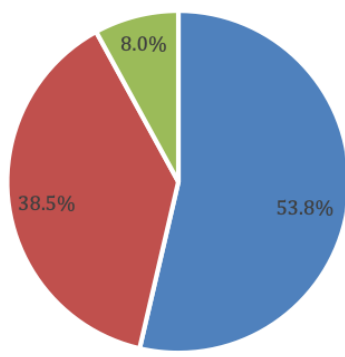

- Yes " No " To Some exten

Figure 5.7: Usage of Green Supply Chain Management Practice is must for the legal compliance

\section{Interpretation}

Based on the above analysis, it is clear that $53.8 \%$ respondents feel that using the Green Supply Chain Management practices is necessary for the legal compliance, $38.5 \%$ respondents denies the same and $8 \%$ respondents feel that to some extent this practice is necessary for the legal compliance.

8. The practice of the green supply chain management significantly impacts the competitiveness in the industry

\begin{tabular}{|l|r|}
\hline Yes & $55.8 \%$ \\
\hline No & $15.4 \%$ \\
\hline Maybe & $28.8 \%$ \\
\hline
\end{tabular}

Table 5.8: Impact of Green Supply Chain Management in the industry

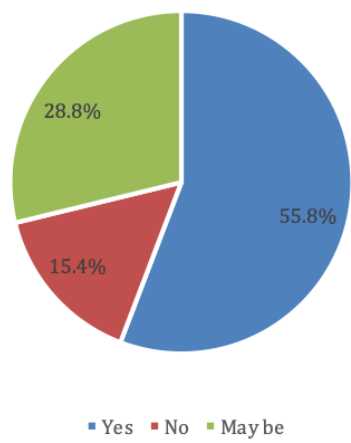

Figure 5.8: Impact of Green Supply Chain Management in the industry

\section{Interpretation}

As per the above analysis, it is clear that $55.8 \%$ respondents feel that the practice of the green supply chain management significantly impacts the competitiveness in the industry, $15.4 \%$ respondents denies the same $\& 28.8 \%$ are not sure about the same.

9. The top management encourages the employees to use the green supply chain management practices

\begin{tabular}{|l|r|}
\hline Strongly agree & $17.3 \%$ \\
\hline Agree & $69.2 \%$ \\
\hline Disagree & $9.6 \%$ \\
\hline Strongly disagree & $4.0 \%$ \\
\hline
\end{tabular}

Table 5.9: Encouragement by top management to use the Green Supply Chain Management Practices

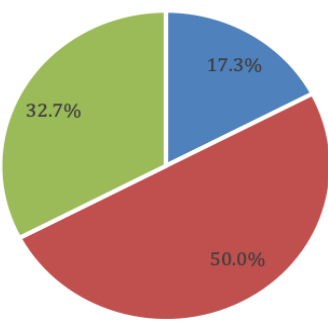

- Yes = To some extent " No

Figure 5.9: Encouragement by top management to use the Green Supply Chain Management Practices

\section{Interpretation}

It is clear from the above analysis, that $17.3 \%$ respondents say that the top management encourages the employees to use the green supply chain management practices, 50\% respondents say that to some extent they do so, and $32.7 \%$ respondents denies the same.

10. The top management has allocated adequate resources to the implementation of the green supply chain management practices.

\begin{tabular}{|l|c|}
\hline Strongly agree & $9.6 \%$ \\
\hline Agree & $69.2 \%$ \\
\hline Disagree & $19.2 \%$ \\
\hline Strongly disagree & $2.0 \%$ \\
\hline
\end{tabular}

Table 5.10: Allocation of adequate resources to the implementation of Green Supply Chain Management Practice

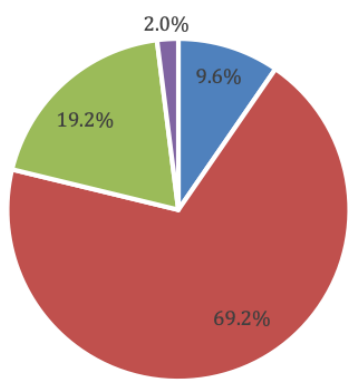

" Strongly agree " Agree " Disagree "Strongly disagree

Figure 5.10: Allocation of adequate resources to the implementation of Green Supply Chain Management Practice

\section{Interpretation}

It is clear from the above analysis that $9.6 \%$ respondents strongly agree that the top management has allocated adequate resources to the implementation of the green supply chain management practices, $69.2 \%$ respondents agrees on the same, $19.2 \%$ disagrees on it \& $2 \%$ strongly disagrees on it.

11. Our competitors have aggressively implemented Green Supply Chain Management

\begin{tabular}{|l|l|}
\hline Yes & $17.3 \%$ \\
\hline To some extent & $50.0 \%$ \\
\hline No & $32.7 \%$ \\
\hline
\end{tabular}

Table 5.11: Implementation of Green Supply Chain Management among competitors 


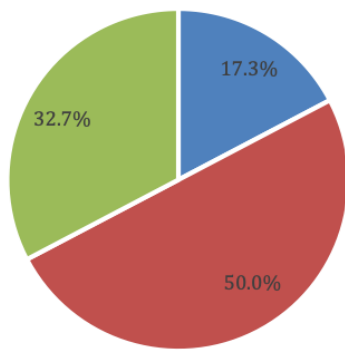

- Yes = To some extent " No

Figure 5.11: Implementation of Green Supply Chain Management among competitors

\section{Interpretation}

It is clear from the above analysis, that $17.3 \%$ respondents says that the competitors have aggressively implemented GSCM, 50\% says that they have implemented it to some extent and $32.7 \%$ respondents denies the same.

12. The IT team has mastered the skills necessary for the projects which are related to GSCM practices

\begin{tabular}{|l|r|}
\hline Yes & $17.3 \%$ \\
\hline To some extent & $71.2 \%$ \\
\hline No & $11.5 \%$ \\
\hline
\end{tabular}

Table 5.12: Mastering of skills that are required for Green Supply Chain Management Practices

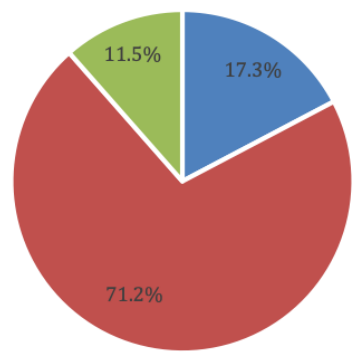

- Yes = To some extent = No

Figure 5.12 : Mastering of skills that are required for Green Supply Chain Management Practices

\section{Interpretation}

It is clear from the above analysis, that $17.3 \%$ respondents feel that the IT team has mastered the skills necessary for the projects which are related to GSCM practices, $71.2 \%$ respondents say that to some extent they have been trained and $11.5 \%$ respondents denies the same.

13. Please indicate the extent that the organization is implementing each of the following

\begin{tabular}{|c|c|c|}
\hline $\begin{array}{l}\text { The purchase of raw materials that can be } \\
\text { reused }\end{array}$ & 20 & $\begin{array}{r}38.5 \\
\%\end{array}$ \\
\hline The purchased products are friendly & 25 & $\begin{array}{r}48.1 \\
\%\end{array}$ \\
\hline $\begin{array}{l}\text { Environmentally harmful products are } \\
\text { avoided }\end{array}$ & 29 & $\begin{array}{r}55.8 \\
\%\end{array}$ \\
\hline
\end{tabular}

Table 5.13: Implementation of Green Supply Chain management

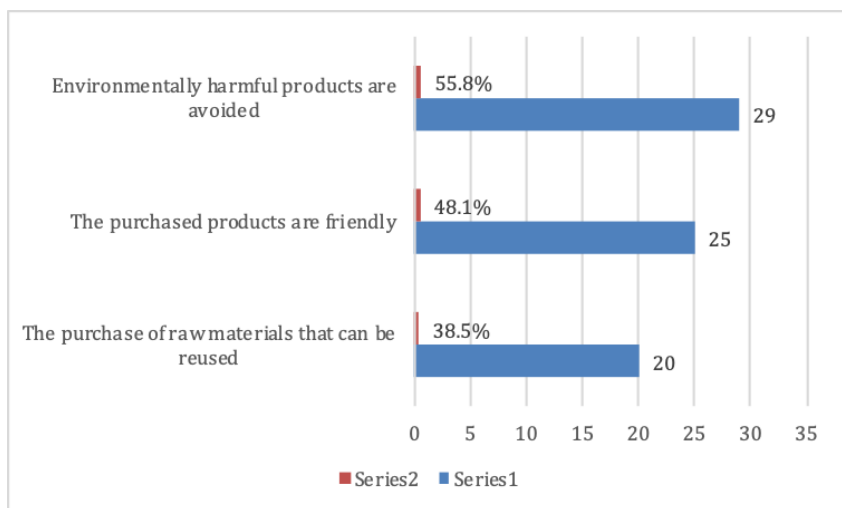

Figure 5.13: Implementation of Green Supply Chain management

\section{Interpretation}

It is clear from the above analysis that $38.5 \%$ respondents say that their organization purchase the raw materials that can be reused, $48.1 \%$ respondents feel that their organization purchases products that are friendly and $55.8 \%$ respondents say that their organization avoids the environmentally harmful products.

\section{OBSERVATIONS}

- It is clear from the above analysis, that $50 \%$ respondents are employed in manufacturing industry, $17 \%$ respondents are employed in Trade i.e. wholesale or retail industry, $5.8 \%$ respondents are employed in Logistics sector, $3.8 \%$ respondents are employed in real estate sector, $2 \%$ respondents are employed in Environmental Waste Disposal sector, 2\% respondents are employed in Consulting sector, $1.9 \%$ respondents are employed in Banking sector, $1.9 \%$ are employed in none of the industries or sectors, $1.9 \%$ are employed in service industry, $1.9 \%$ are employed in service based industry, $1.9 \%$ are employed in education sector, $1.9 \%$ are employed in metal testing industry, $1.9 \%$ are employed in software industry, $1.9 \%$ are employed in construction sector, $1.9 \%$ are employed in banking sector \& $1.9 \%$ are employed in engineering \& sustaining industry.

- The implementation of Green Supply Chain Management, the impact of corporate social responsibility is $36.5 \%$, organizational policies is $34.6 \%$, top management commitment is $19.2 \%$ and customers is $9.6 \%$.

- The barriers for implementing the Green Supply Chain Management, cost factor plays an important role i.e. the impact of this factor is $32.7 \%$, followed by Unawareness of customers i.e. $34.6 \%$, Corruption is $7.8 \%$, Technology is $9.6 \%$, Government Legislations is $9.6 \%$, cost as well as technology along with customer awareness is $1.9 \%$, consumer behavior, market nerve and alternatives to the products is $1.9 \%$ and NA category is $1.9 \%$.

- $55.8 \%$ respondents says that their top management is aware of the concept \& benefits of Green Supply Chain Management, $9.6 \%$ denies the same and $34.6 \%$ says that they are not sure that the top management is aware of the same.

- $26.9 \%$ respondents say that their organizations have applied the Green Supply Chain Management 
Practices, $48.1 \%$ respondents say that to some extent it has been applied and $25 \%$ respondents denies the same.

- The organization uses $57.7 \%$ of the environmentally friendly packaging, $26.9 \%$ of Green Logistics, $21.2 \%$ of Green Procurement, 25\% of Green suppliers, 3.8\% of recycling of waste, $3.8 \%$ of life sciences \& into green manufacturing, $1.9 \%$ denies the same $\& 1.9 \%$ are not sure about the same.

- $53.8 \%$ respondents feel that using the Green Supply Chain Management practices is necessary for the legal compliance, $38.5 \%$ respondents denies the same and $8 \%$ respondents feel that to some extent this practice is necessary for the legal compliance.

- $55.8 \%$ respondents feel that the practice of the green supply chain management significantly impacts the competitiveness in the industry, $15.4 \%$ respondents denies the same $\& 28.8 \%$ are not sure about the same.

- $17.3 \%$ respondents say that the top management encourages the employees to use the green supply chain management practices, $50 \%$ respondents say that to some extent they do so and $32.7 \%$ respondents denies the same.

- $9.6 \%$ respondents strongly agree that the top management has allocated adequate resources to the implementation of the green supply chain management practices, $69.2 \%$ respondents agrees on the same, $19.2 \%$ disagrees on it \& $2 \%$ strongly disagrees on it.

- $17.3 \%$ respondents says that the competitors have aggressively implemented GSCM, 50\% says that they have implemented it to some extent and $32.7 \%$ respondents denies the same.

- $17.3 \%$ respondents feel that the IT team has mastered the skills necessary for the projects which are related to GSCM practices, $71.2 \%$ respondents say that to some extent they have been trained and $11.5 \%$ respondents denies the same.

- $38.5 \%$ respondents say that their organization purchase the raw materials that can be reused, $48.1 \%$ respondents feel that their organization purchases products that are friendly and $55.8 \%$ respondents say that their organization avoids the environmentally harmful products.

\section{CONCLUSION}

Green Supply Chain Management (GSCM) is evolved from the term supply chain management. The aim of GSCM is to minimize or totally removal of wastages which includes harmful chemicals, emissions \& solid waste. This concept is gaining popularity in all the developed \& developing countries. It also helps in reducing the environmental pollution and production costs along with the increase in customer satisfaction, positive image, good reputation and better opportunities to export the products in proenvironmental countries like USA, UK etc. It also helps in decreasing the ecological impact of the activities related to industries without compromising the quality, cost, reliability, performance and the energy utilization.

It is clear from the above analysis, that maximum respondents are employed in manufacturing industry, followed by trade, the top Management is aware of the concept and benefits related to Green Supply Chain Management, has allocated adequate resources for the implementation of these practices, the same has been applied in their organizations as well. The impact of the implementation of Green Supply Chain Management is in CSR activities. Further, there are certain barriers in implementing Green Supply Chain and the most important factor is played by cost which is followed by other factors like corruption, unawareness of customers etc. Most of the respondents feel that it is necessary for the legal compliance and also impacts the competitiveness in the industry. Most of the organizations have already started using Environmentally Friendly Packaging, Green Logistics, Green Suppliers, Green Procurement and Green Manufacturing. The IT team has mastered the skills related to the practices that are involved in successfully implementing Green Supply Chain Management practices.

\section{REFERENCES}

[1] Kelle \& Silver. Environmental Purchasing : A Framework for Theory Development. European Journal of Purchasing \& Supply Management, Vol. 7,No.1, 64-75, 1989.

[2] Navin Chandra. Green supply chain management, economic growth and environment: A GMM based evidence. Journal of Cleaner Production. 2017;185:588-599, 1991.

[3] Kleindorfer PR, Singhal K, Wassenhove LN. Sustainable operations management. Production and Operations Management. 2005;14(4):482492

[4] Khan et al , Study of Green Supply Chain Management in the Indian Manufacturing Industries: A Literature Review cum an Analytical Approach for the measurement of performance, IJCEM International Journal of Computational Engineering \& Management, Vol. 13, July 2017

[5] P Rao \& D Holt, 2007. Do green supply chains lead to competitiveness and economic performance? International Journal of Operations and Production Management 25(9):898-916.

[6] M Hajikhani, Wahat \& KB Idris, 2000. Considering on green supply chain management drivers as a strategic organizational development approach; a Malaysian perspective. Australian Journal of Basic and Applied Sciences 6(8):146-165.

[7] D Holt \& A Ghobadian, 2010 "An Empirical Study of Green Supply Chain Management.

[8] RO Large \& CG Thomsen, 2012 "Drivers of Green Supply Chain Management Performance: Evidence from Germany", Journal of Purchasing and Supply Management, Vol. 17, pp 176-184.

[9] TY Chiou, HK Chan, F Lettice \& SH Chung, S.H., (2012) "The Influence of Greening the Suppliers and Green Innovation on Environmental Performance and Competitive Advantage in Taiwan", Transportation Research Part E, 47, pp 822-836.

[10] AMF Paco, MLB Raposo, WL Filho, 2010. Identifying the green consumer: a segmentation study. Journal of Targeting, Measurement and Analysis for Marketing 17(1):17-25

[11] M Balaji, V Velmurugan, PK Manikanda, 2015. Barriers in green supply chain management: an Indian foundry perspective. International Journal of Research in Engineering and Technology 3(7):423-429.

[12] A Kamolkittiwong \& B Phruskaphanrat, 2016. An analysis of drivers affecting green supply chain management implementation in electronics industry in Thailand. Journal of Economics, Business and Management 3(9):864-869.

[13] Practices amongst UK Manufacturers", Journal of Manufacturing Technology, Vol. 20, No. 7, pp 933-956. 
[14] D Holt \& A Ghobadian, 2010 "An Empirical Study of Green Supply Chain Management Practices amongst UK Manufacturers", Journal of Manufacturing Technology, Vol. 20, No. 7, pp 933-956

\section{APPENDIX}

1. What is the primary type of the business conducted by your organization

- Manufacturing

- Trade i.e. wholesale or retail

- Logistics

- Real Estate

- Environmental Waste Disposal

- Consulting

- Banking

- None

- Service

- Service based

- Education

- Metal Testing

- Software

- Construction

- Banking

- $\quad$ Engineering \& sustaining

2. What are the drivers of implementation of Green Supply Chain Management

- Corporate social responsibility

- Organizational Policies

- Top management commitment

- Customers

3. What are the barriers in implementation of green supply chain management

- Cost

- Unawareness of customers

- Corruption

- Technology

- Government Legislations

- Cost as well as technology along with consumer unawareness

- Consumer behavior, market nerve and alternatives to your product

- NA

4. Is the top management of your company aware of the concept $\&$ benefits of Green Supply Chain Management

- Yes

- No

- May be

5. Does the organization use Green Supply Chain Management Practices like Green Supplies, Green Manufacturing, Green Packaging, Green Logistics

- Yes

- To some extent

- No

6. Which of the following practices does your organization uses

- Green Procurement

- Green Logistics

- Environmentally friendly packaging
- Green Suppliers

- Recycling of waste

- Life sciences and into green manufacturing

- None at present

- Not sure

7. What do you think that using the Green Supply Chain Management practices is necessary for the legal compliance

- Yes

- No

- To some extent

8. The practice of the green supply chain management significantly impacts the competitiveness in the industry

- Yes

- No

- May be

9. The top management encourages the employees to use the green supply chain management practices

- Strongly agree

- Agree

- Disagree

- Strongly disagree

10. The top management has allocated adequate resources to the implementation of the green supply chain management practices.
- Strongly agree

- Agree

- Disagree

- Strongly disagree

11. Our competitors have aggressively implemented GSCM

- Yes

- To some extent

- No Idea

12. The IT team has mastered the skills necessary for the projects which are related to GSCM practices

- Yes

- To some extent

- No Idea

13. Please indicate the extent that the organization is implementing each of the following

- The purchase of the raw material that can be reused

- The purchase products are friendly

- Environmentally harmful products are avoided 